a rapidly growing income. The country clearly needs help with eapital expenditure on education, but above all it needs a supply of men and women from overseas, especially teachers and trainers of teachers who can work with the Africans when independence comes. Together they can bring into being a genuine African system of education; such a system must recognize the special needs of Uganda, a country which must succeed in agriculture in a modern world; the system must also gradually produce a professional class to undertake in all spheres the management of Uganda's affairs by the Africans themselves.

\section{THE REVOLUTION IN AGRICULTURE}

$\mathrm{T}$

HE subject of the presidential address to Section M (Agriculture), given by Sir William Slater, was "The Revolution in Agriculture". In his opening remarks, Sir William directs attention to the fact that agricultural revolutions have their origins in economic and social causes, but the impetus which carries them forward is provided by the technical advances brought into use to meet the new situation. When the forces which have started a revolution have spent themselves or been contained, the revolution continues, if there are no further social or economic uphervals, until the new techniques have been absorbed into agriculture and a new stable system of farming has emerged.

The revolution through which we are now passing had its origins in the First World War. The threat to food supplies in Britain gave a great stimulus to agricultural research. Although farming went through a period of acute depression during the inter-war years, the research continued. The mon were fow and the equipment often inadequate, but the output of work was both considerable in quantity and high in quality. New teahniques were developed and the old improved; most important of all, a store of fundamental knowledge was built up and was available as a basis for the solution of applied problems as they arose.

When war again called for a great increase in agricultural production, it was obtained, not by returning to the high arable farming of the nineteenth century, but by applying the techniques made available by research to develop an entirely new high level of production. The first step in increasing food production in 1939 was as in 1916, the ploughing of permanent pasture. From the outset, however, there was no intention to return to the high arable farming of the past, but instead a firm determination to move forward into a new scientifically based agriculture. Government and farmers alike looked to the raising of agricultural production not as a war-time measure only but as a pattern of farming for the future. While steps were taken for the immediate increase of production, it was always in the minds of those responsible at all levels that the ultimate objective was a steadily rising standard of efficiency. No limit in time or extent was set to this programme; it was tacitly accepted that efficiency would continue to rise so long as the scientists produced and the farmers applied the knowledge necessary to maintain steady progress.

The meaning of agricultural efficiency was not however defined. During the War, it meant the maximum yield almost regardless of cost. After the War the farmers still thought of efficiency as maxi- mum production at guaranteed prices, while the Government began to regard efficiency in the terms of the lowering of costs and the limitation of subsidized production.

The full effect of the new techniques was not felt until after the Second World War, when yields rose steeply. This increased output was achieved with a diminished labour force and a high level of mechaniza. tion. The rise in output will continue, if no economic or political brake is put on the technical progress. It is not, however, a uniform rise over the industry as a whole. The progressive farmers are obtaining yields well above the average, while others are lagging far behind. British agriculture has reached a point of decision; it can either press forward applying every technique made available by science, and fit itself over the next decade to face any fair competition without subsidies, or rest at the present level of efficiency and trust to the continuation of subsidies for its future prosperity. If it takes the first road, the industry will have to be re-organized into larger units. The present structure, in which one man in three is a master, is quite unsuited to the rapid application of scientific methods, both in husbendry and in management. However such a re-organiza. tion takes place, it will be difficult and often painful, but an agriculture based on a high level of efficiency will have a far surer future than one which rests on politicel willingness to continue indefinite support by subsidies.

\section{AFRICAN JURISPRUDENCE}

$M$ AJOR difficulties in the sociology of 'law' arise from controversy over the way in which this word of many meanings is used. It, and other unrelated words, have no one intrinsic, strict meaning; and criticism which is based on objection to another scholar using a particular meaning of the word is unjustified. These difficulties might be avoided if better use were made of the wealth of English, so that different phenomena-institutions, concepts, processes-could be distinguished by the use of different words, like legal, forensic, adjudication, litigation, etc., while perhaps retaining 'law' as a word of multiple meaning because of its general usefulness in analysis.

The problems of "African Jurisprudence", the subject of Prof. M. Gluckman's presidential address to Section N (Sociology), must then be broken into several different series, each distinguished by a separate word. Each of these series requires to be distinguished in order that we should be clear as to which one we are dealing with at any moment, and in order that we should be able to examine the effect of different kinds of phenomena on one another. It is particularly important to aohieve this distinguishing clarity if we are to relate jurisprudential problems to the social relations in which they are involved, which is the main task of social anthropology.

For example, if we look at the study of the judicial process, we find that there are anthropologists who have insisted that this process in African tribes is so different from the similar process in the West that we cannot translate the concepts of Africans about this process into our own concepts. This would be cultural solipsism, exoluding comparative generalizing. But if we examine the situations from which 